\title{
Pengembangan Prototype Software Real Time Monitoring Berbasis Data Automatic Identification System (AIS)
}

\author{
A.A.B. Dinariyana1, Ketut Buda Artana1, Kriyo Sambodho2 \& Dwi Kristianto3 \\ 1Departemen Teknik Sistem Perkapalan, Fakultas Teknologi Kelautan, ITS Surabaya \\ 2Departemen Teknik Kelautan, Fakultas Teknologi Kelautan, ITS Surabaya \\ 3Departemen Teknik Informatika, Fakultas Teknologi Informasi, ITS Surabaya \\ kojex@its.ac.id
}

\begin{abstract}
Abstrak
Perangkat Automatic Identification System (AIS) adalah salah satu perangkat yang wajib dipasang pada kapal berukuran lebih besar dari 300 GT. Penggunaan perangkat AIS dimaksudkan untuk meningkatkan keamanan dan keselamatan di laut (SOLAS, Safety of Life at Sea). Penelitian ini merupakan kelanjutan dari penelitian yang telah dilakukan sebelumnya terkait dengan pemanfaatan AIS untuk inspection score pengawasan kapal dan monitoring pipa bawah laut. Hasil-hasil penelitian tersebut mendasari pembangunan konsep dasar sebuah prototype software real time monitoring berbasis AIS. Prototype yang dikembangkan saat ini adalah monitoring real time untuk anjungan lepas pantai dan pipa bawah laut, skor inspeksi kapal, dan ship tracking. mengolah data AIS sedemikian rupa dan membandingkan dengan lokasi fasilitas anjungan lepas pantai dan pipa bawah laut. Monitoring anjungan lepas pantai dan pipa bawah laut memungkinan dalam kondisi bahaya, sistem akan mengirimkan peringatan dini melalui notifikasi telepon seluler, surat elektronik dan media komunikasi lain. Sistem inspeksi kapal bermaksud untuk memonitor lalu lintas kapal dalam daerah perairan tertentu. Oleh otoritas pelabuhan, fitur ini dapat digunakan untuk memudahkan dalam menentukan prioritas kapal-kapal yang akan dilakukan inspeksi. Fitur lainnya yang dikembangkan adalah sistem data historis, yaitu penampilan kembali vessel track dalam kurun waktu, batas daerah perairan atau untuk memperlihatkan jalur/track beberapa kapal tertentu. Pengembangan prototype software ini diharapkan dapat berkontribusi dalam meningkatkan keamanan dan keselamatan operasional kapal dan fasilitas lepas pantai/bawah laut serta meningkatkan efisiensi dalam melakukan monitoring terhadap lalu lintas laut.
\end{abstract}

Kata kunci: AIS, Inspeksi Kapal, Real Time Monitoring, Ship Tracking, Pipa Gas Bawah Laut

\section{PENdahuluan}

Kecelakaan kapal tidak hanya berakibat fatal pada kapal, muatan dan awak kapal, tetapi juga berdampak langsung pada lingkungan laut maupun daerah pesisir. Kerugian lingkungan meliputi biaya penanggulangan pencemaran, kompensasi terhadap terganggunya industri perairan laut dan pesisir. Kerugian lainnya adalah kerugian akibat hilangnya kesempatan berusaha akibat pencemaran yang terjadi. Pada tahun 2009, terjadi 293 kasus kecelakaan besar yang dilaporkan oleh Mahkamah Pelayaran, terdiri dari: kapal tenggelam (31\%), kapal kandas (25\%), kapal tabrakan $(18,27 \%)$, kapal terbakar $(9,67 \%)$ dan lainnya (16,06\%) (Indonesia M. P., 2009). Penyebab dari kecelakaan-kecelakaan kapal tersebut adalah 78,45\% kesalahan manusia, 9,67\% kesalahan teknis, 1,07\% faktor cuaca, dan 10,75\% karena kombinasi cuaca dan kesalahan teknis. Berdasarkan IMO Resolution MSC.74(69) ((IMO)), AIS diwajibkan penggunaannya dalam operasional kapal berkapasitas diatas 300 GT. Regulasi pemanfaatan AIS ini bertujuan untuk mengurangi frekuensi terjadinya tubrukan kapal. Piranti AIS secara otomatis mengirimkan data dinamis berupa lokasi, kecepatan, course dan heading serta data statis berupa lebar, panjang, draft serta informasi pelengkap lainnya. Saat ini, AIS tidak hanya digunakan di kapal, tetapi lebih jauh lagi digunakan untuk pemantauan lalu lintas kapal di perairan tertentu yaitu vessel monitoring system (VTS).

AIS juga dapat digunakan sebagai sarana untuk monitoring fasilitas laut baik yang terapung maupun yang berada dibawah permukaan air. Seperti yang telah diketahui, sebagian besar kekayaan minyak dan gas bumi (migas) yang dimiliki Indonesia berada di laut sehingga salah satu cara untuk mendistribusikan hasil migas ini adalah melalui pipa distribusi yang berada di bawah perairan/laut. Terdapat beberapa potensi bahaya yang dapat terjadi, khusunya untuk pipa bawah laut dan anjungan lepas pantai yang terkait dengan operasional kapal-kapal yang berlayar pada perairan dimana fasilitas tersebut berada. Potensi bahaya yang mungkin timbul antara lain: anchor drop, anchor drag, kapal tenggelam, serta tubrukan kapal dengan anjungan lepas pantai. Sistem peringatan dini (SPD) yang telah dibangun memanfaatkan data posisi pipa bawah laut dan anjungan lepas pantai serta data dinamis kapal yang didapatkan dari AIS secara real time. Jarak relatif kapal dengan pipa bawah laut atau anjungan lepas pantai dapat dihitung secara akurat dan secara real time. Batas-batas daerah terlarang dan daerah terbatas pipa bawah laut dan anjungan lepas pantai juga dapat digunakan sebagai acuan untuk memicu notifikasi SPD. Teknik hamparan digunakan untuk melengkapi interface SPD sehingga pergerakan kapal dan jarak relatifnya terhadap pipa bawah 
laut dan anjungan lepas pantai dapat dipantau secara visual. Pemantauan secara visual akan memudahkan bagi pihak-pihak otoritas dan perusahaan yang mengoperasikan fasilitas tersebut.

Berdasarkan Peraturan Menteri Perhubungan Nomor 68/2011, pemerintah telah menetapkan beberapa daerah pengamanan pipa bawah laut, anjungan lepas pantai dan kabel laut dengan ketentuan sebagai berikut: a) daerah terbatas pipa dan kabel laut, adalah daerah disebelah kanan dan kiri titik terluar pipa hingga jarak 1250 meter. b) daerah terlarang anjungan lepas pantai, adalah daerah pada jarak 500 meter dari pinggir terluar anjungan lepas pantai. c) daerah terbatas anjungan lepas pantai, adalah daerah pada jarak 1750 meter dari pinggir terluar atau sekitar 1250 meter dari daerah terlarang anjungan lepas pantai.

Rendahnya penerapan standar keselamatan adalah salah satu pemicu tingginya tingkat kecelakaan kapal di laut Indonesia. Tokyo MOU Annual Report 2009 [1] telah mewajibkan pihak otoritas pelabuhan untuk melakukan inspeksi pada 25\% populasi kapal asing di area pelabuhan di Indonesia. Operasional otoritas pelabuhan dan stakeholder pelabuhan membutuhkan sistem ranking prioritas inspeksi yang memudahan pelaksanaan inspeksi kapal. Untuk pelabuhan dengan populasi kapal yang sangat banyak, daftar peringkat skor inspeksi perlu dibuat untuk memudahkan memilih kapal yang akan diinspeksi. Sistem peringkat disusun menggunakan skor inspeksi. Skor inspeksi setiap kapal ditentukan dengan melakukan pembobotan melalui metode analytical hierarchy process (AHP) terhadap variabel-variabel inspeksi yang telah ditetapkan pada Tokyo MOU. Input perhitungan skor inspeksi adalah data AIS dan data spesifikasi kapal. Hasil perhitungan skor inspeksi ditampilkan pada peta digital untuk memudahkan pengamatan secara visual. Sama seperti SPD, Sistem Skor Inspeksi (SSI) berjalan secara waktu nyata dan ditampilkan di peta digital.

Paper ini memaparkan tentang pengembangan propotipe fasilitas pemantauan keselamatan kapal berbasis data AIS dari kajian-kajian yang telah dilakukan sebelumnya [2] [3] diantaranya adalah: a) Sistem Peringatan Dini (SPD) terhadap bahaya yang berpotensi terjadi pada pipa bawah laut dan anjungan lepas pantai. Dalam peta digital diplotkan posisi pipa bawah laut dan anjungan lepas pantai serta posisi dan gerakan kapal yang didapatkan secara waktu nyata dari data AIS. b) Sistem Skor Inspeksi (SSI) terhadap kapal yang akan memasuki pelabuhan. Tingkat kebahayaan kapal dijadikan sebagai indikator keterdesakan melakukan inspeksi terhadap kapal. SSI menggabungkan data AIS secara waktu nyata dan database kapal.

\section{SISTEM PERINGATAN DINI}

Data AIS terdiri dari beberapa informasi yang dapat dikategorikan kedalam data statis dan data dinamis. Data yang berkaitan dengan informasi posisi kapal dikategorikan sebagai data dinamis. Data-data dinamis inilah yang kemudian diterjemahkan kedalam data-data numerik berupa koordinat geografis posisi kapal, yaitu latitude dan longitude. Selain data lokasi kapal, ada beberapa data lain yang digunakan untuk menentukan kondisi keterbahayaan kapal terhadap sebuah objek tertentu, antara lain: status navigasi, arah kapal (heading/course), kecepatan kapal (speed over ground) dan waktu terakhir kapal mengirimkan data. Objek yang dimaksud adalah fasilitas bawah air ataupun fasilitas terapung dan daerah yang dinilai vital untuk dilindungi dari lalu lintas kapal yang beroperasi pada daerah perairan. Data AIS yang diterima oleh AIS base station bersama dengan data-data lain termasuk diantaranya data master kapal dan data lingkungan dibandingkan dengan lokasi objek yang menjadi perhatian. Bila hasil analisis menyatakan bahwa objek dalam kondisi bahaya, maka sistem akan secara otomatis mengirimkan peringatan (Gambar 1).

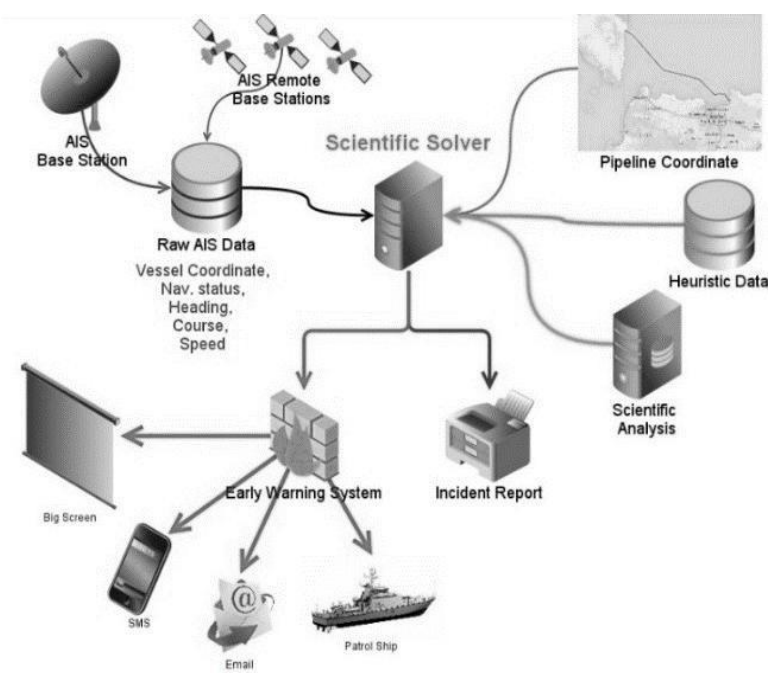

Gambar 1. Konsep dasar perangkat lunak AIS ITS

Prototype monitoring dikembangkan dengan menggunakan script engine PHP dan beberapa perangkat lunak open source. Komunikasi serta perpindahan data AIS antar perangkat lunak bisa diamati pada Gambar 2 berikut ini. 


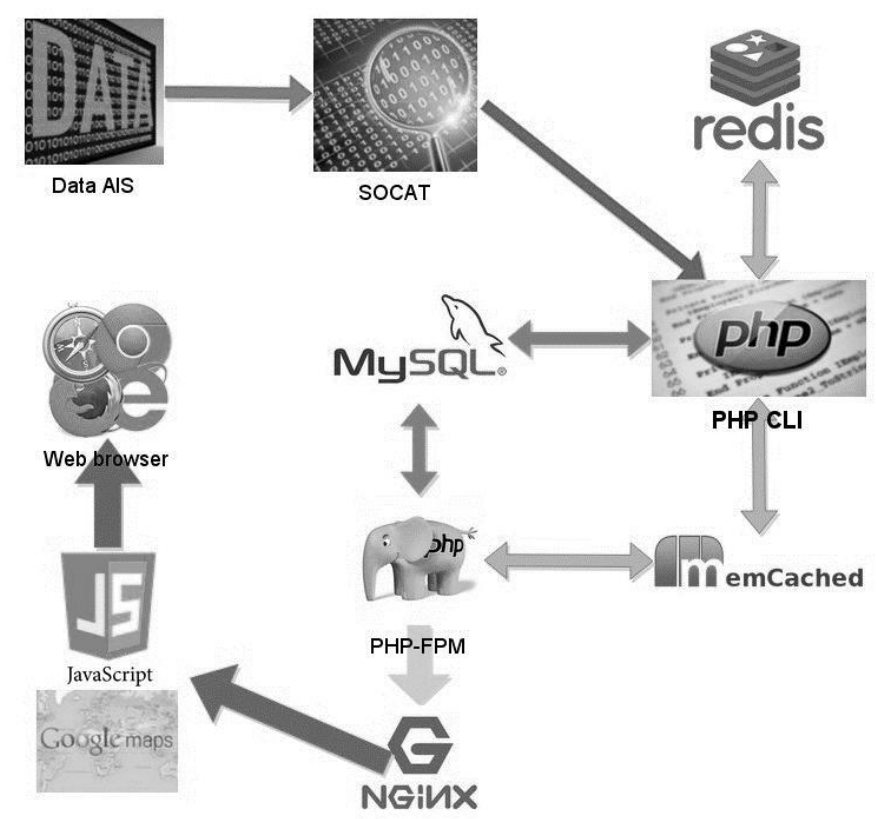

Gambar 2. Interkoneksi perangkat lunak AIS

Keseluruhan perangkat lunak diatas dijalankan diatas sistem operasi Linux Debian 64bit versi 7.8 (Wheezy). Untuk memenuhi kebutuhan sistem komputasi yang gegas dan stabil, repository standard Linux Debian tidak menyediakan rilis terbaru perangkat lunak-perangkat lunak diatas, maka diputuskan untuk menggunakan third party repository, yaitu dotdeb.org. Salah satu fitur terpenting tidak ada di repository standard adalah fitur OpenGIS (Open Geographic Information System) yang hanya ada sejak mySQL versi 5.6 dan mySQL 5.6 hanya tersedia di repository dotdeb.

\section{PENENTUAN SKOR INSPEKSI KAPAL}

Berdasarkan Tokyo MOU 2009, adapun kriteria-kriteria yang mempengaruhi target inspeksi kapal yang diwenangkan oleh port state control diantaranya adalah: negara bendera (flag state), biro klasifikasi, usia kapal, dan tipe kapal. Pada sistem yang dibangun pada prototype monitoring ini bahwa penentuan prioritas inspeksi kapal didasarkan pada skor yang diberikan dari tiap bobot pada kriteria dan sub-kriteria yang dianalisa dengan menggunakan metode AHP. Tabel 1 berikut memperlihatkan skor inspeksi untuk kriteria flag state yang nantinya digunakan sebagai salah satu dasar untuk menentukan prioritas kapal-kapal yang akan diinspeksi oleh otoritas pelabuhan.

Table 1 Nilai fungsi dan skor inspeksi dari kriteria dan subkriteria flag state

\begin{tabular}{lccc}
\hline Criteria & Weight & Function & Inspection Score \\
\hline Flag State & $\mathbf{0 . 3 0 6}$ & $\mathbf{1 0 0 0}$ & \\
Sub Criteria: & & & \\
Indonesia & 0.082 & 306 & 25.092 \\
China & 0.086 & 306 & 26.316 \\
Korea & 0.066 & 306 & 20.196 \\
Panama & 0.095 & 306 & 29.07 \\
Filipina & 0.151 & 306 & 46.206 \\
Cambodia & 0.252 & 306 & 77.112 \\
Cyprus & 0.062 & 306 & 18.972 \\
Hongkong & 0.072 & 306 & 22.032 \\
Liberia & 0.086 & 306 & 26.316 \\
Singapore & 0.048 & 306 & 14.688 \\
\hline
\end{tabular}

\section{PENGEMBANGAN SOFTWARE MONITORING}

\subsection{Outer Bounding Rectangle}

Beban komputasi pengolahan data AIS sangat dipengaruhi oleh beberapa parameter utama, antara lain: jumlah kapal, jenis klas AIS dan jumlah serta kompleksitas objek bawah air dan/atau daerah perairan yang akan dipantau. Jumlah variasi data yang sangat besar tersebut, mengakibatkan menurunnya kapasitas komputasi server bila proses perhitungan dilakukan untuk semua data (semua kapal dan semua objek berada di bawah permukaan laut). Cara yang dapat digunakan untuk 
membatasi jumlah data yang harus dihitung adalah menggunakan konsep dasar R-Tree Indexing. Konsep dasar R-Tree cukup sederhana yaitu membuat outer bounding rectangle (OBR) dari setiap objek, kemudian menggabungkan setiap OBR yang berdekatan, bersinggungan dan/atau yang menjadi subset sebuah OBR lain menjadi OBR yang lebih besar lagi.

Konsep dasar R-Tree Indexing digunakan untuk menentukan apakah sebuah kapal tertentu, dengan lokasi tertentu dalam waktu tertentu layak untuk menjadi kandidat data yang akan diolah di proses komputasi selanjutnya. Kriteria dasar inilah yang dipakai untuk membatasi himpunan data kapal sehingga didapatkan sebagian data kapal saja dari himpunan data kapal. Untuk lebih jelasnya algoritma pemeriksaan lokasi kapal dengan OBR dapat dilihat pada Gambar 3 berikut ini:

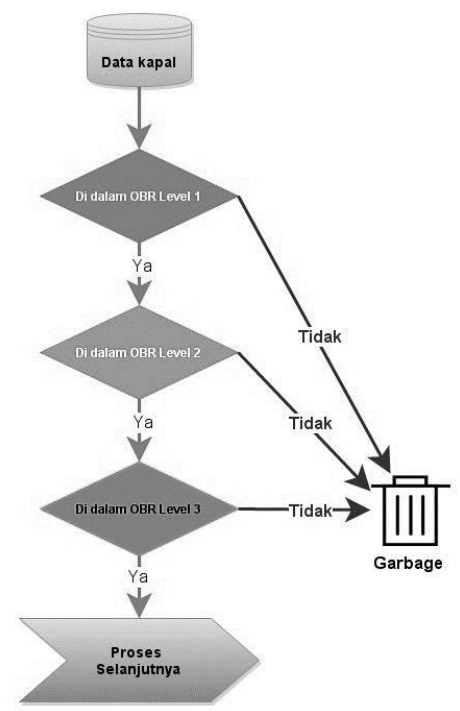

Gambar 3. Algoritma pemeriksaan lokasi kapal dengan OBR

Bila di akhir proses pemeriksaan lokasi kapal menggunakan OBR sama sekali tidak ada data kapal yang termasuk dalam OBR, maka sistem menganggap bahwa tidak ada kapal yang perlu diperiksa jaraknya terhadap objek tertentu karena jaraknya terlalu jauh.

\subsection{Perhitungan jarak kapal terhadap objek}

Perhitungan jarak kapal terhadap suatu objek tertentu juga tidak bisa hanya dengan menghitung jarak tegak lurus kapal terhadap sebuah garis tetapi juga memperhatikan lokasi kapal terhadap segmen pipa (Gambar 5 dan Gambar 5).

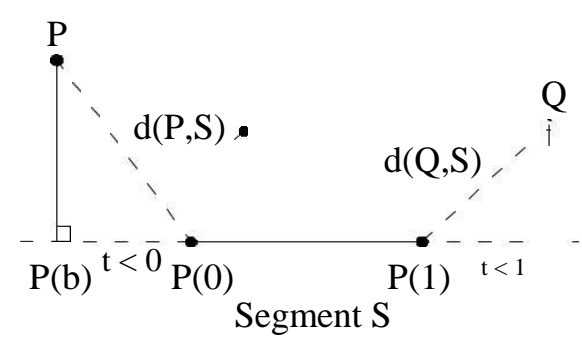

Gambar 4. Jarak terpendek tegak lurus

Untuk setiap segmen Ray R, jarak terpendek titik P terhadap segmen bukanlah P-P(b) akan tetapi P-P(0).

$$
\begin{aligned}
& \mathbf{w}_{0}=P-P_{0} \text { and } \theta_{0} \in\left[-180^{\circ}, 180^{\circ}\right] \\
& \mathbf{w}_{0} \cdot \mathbf{v} \leq 0 \\
& \Leftrightarrow\left|\theta_{0}\right| \geq 90^{\circ} \\
& \Leftrightarrow \mathrm{d}(P, \mathbf{S})=\mathrm{d}\left(P, P_{0}\right) \\
& \mathbf{w}_{1}=P-P_{1} \text { and } \theta_{1} \in\left[-180^{\circ}, 180^{\circ}\right] \\
& \mathbf{w}_{1} \cdot \mathbf{v} \geq 0 \Leftrightarrow \mathbf{w}_{0} \cdot \mathbf{v} \geq \mathbf{v} \cdot \mathbf{v} \\
& \Leftrightarrow\left|\theta_{1}\right| \leq 90^{\circ} \\
& \Leftrightarrow \mathrm{d}(P, \mathbf{S})=\mathrm{d}\left(P, P_{1}\right)
\end{aligned}
$$

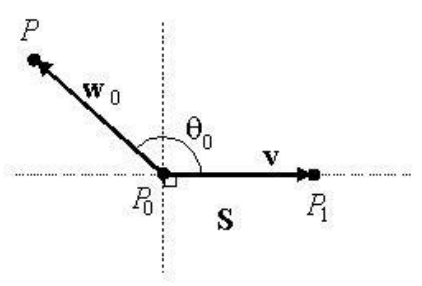

Gambar 5. Jarak poin ke segmen

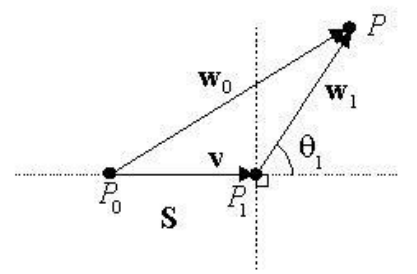


Memperhatikan kondisi diatas maka perhitungan jarak didahului dengan menghitung sudut antara titik lokasi kapal terhadap ujung-ujung segmen pipa. Bila dalam salah satu sudut tegak lurus, maka formula jarak terpendek tegak lurus digunakan.Bila tidak, maka jarak terpendek dihitung pada masing-masing ujung segmen pipa [4].

\subsection{Fitur-Fitur AIS ITS}

Pada bagian ini akan diberikan beberapa fitur yang telah dikembangkan pada prototype ini. (1) Locate, berfungsi untuk membantu menemukan lokasi kapal di peta dan memindah posisi tengah peta di lokasi koordinat kapal. (2) Zoom, fitur ini berfungsi untuk menambah tingkat zoom peta (zoom in). Fitur zoom juga memindah titik tengah peta ke lokasi kapal. (3) Ship info, fitur ini berfungsi untuk menampilkan infowindow (jendela informasi) yang berisi data-data AIS dan data master kapal. Data yang ditampilkan dalam infowindow adalah data AIS terbaru yang diterima oleh server. (4) Base Map, sama seperti perangkat lunak GIS pada umumnya, perangkat lunak AIS ITS juga menggunakan base map yang digunakan untuk visualisasi data lokasi kapal, data lokasi pipa dan juga data lokasi struktur bangunan laut. Ada beberapa sumber utama yang digunakan sebagai base map, antara lain: Open Street Map (omniscale.net), Map Quest (mapquest.com), Carto Light (cartodb.com), Stamen (stamen.com), Open Street Browser (openstreetbrowser.org), Ovi Normal Day (ovi.com), dan Ovi Satellite (ovi.com). (5) Rangking Skor Inspeksi, yang berisikan daftar kapal yang diurutkan berdasarkan nilai skor inspeksi. (6) Tracking Kapal, dalam menganalisis insiden kapal dan kecelakaan, kebutuhan data historis sebelum kejadian/kecelakaan sangat penting. Pemeriksaan atas upaya risiko dan mitigasi yang diperlukan untuk memastikan kecelakaan yang sama tidak terulang. Aplikasi yang dikembangkan dalam penelitian ini juga menyediakan fitur untuk melacak jalur kapal, dua kapal atau sekelompok kapal dalam durasi waktu tertentu dan dalam area tertentu. Data historis pergerakan kapal dapat digunakan untuk melakukan penyelidikan forensik sehingga analisis dan rekomendasi yang akan dihasilkan bisa lebih akurat. Screenview dari fitur-fitur yang telah dikembangkan dapat dilihat pada gambar-gambar berikut.
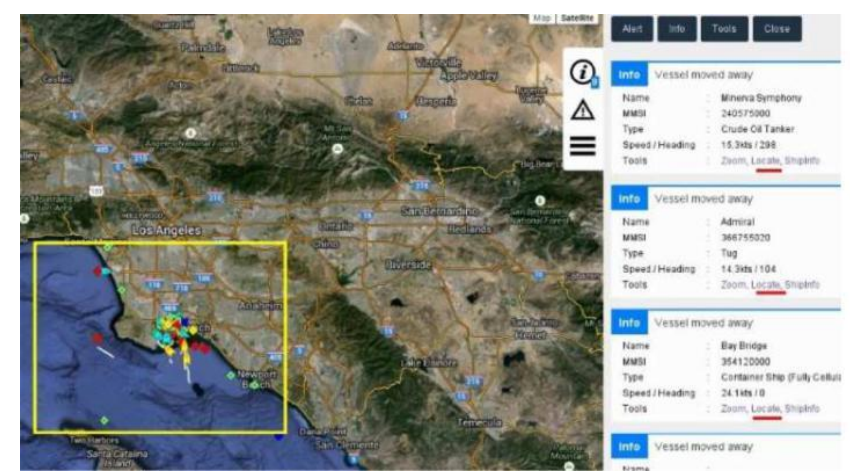

(a) Fitur Locate

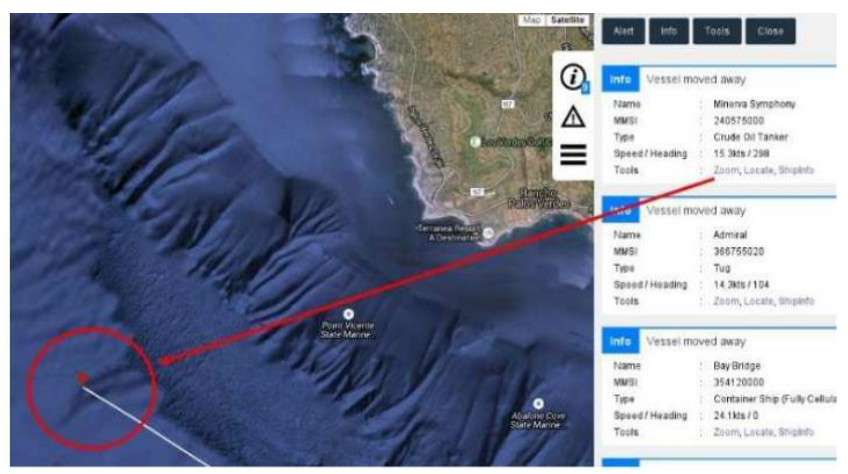

(b) Fitur Zoom

Gambar 6. Screenview dari fitur Locate dan Zoom

\begin{tabular}{|c|c|c|}
\hline Name & : Bow Fraternity & $x$ \\
\hline MMSI & $: 563621000$ & \\
\hline IMO & $: \quad 8420517$ & \\
\hline Callsign & : S6BV7 & \\
\hline Type & $\begin{array}{l}\text { Chemical/Products } \\
\text { Tanker }\end{array}$ & \\
\hline Flag & : Singapore & \\
\hline Class & : Det Norske Veritas & \\
\hline Age & $: \quad 1986-6-6$ (29 years) & \\
\hline Insp.Score & : 156.292 (Medium Risk) & \\
\hline GT & : 27,963 & \\
\hline DWT & $: \quad 45,507$ & \\
\hline Length & $: \quad 176.84 \mathrm{~m}(\mathrm{lbp}: 169.02 \mathrm{~m})$ & \\
\hline Width & $: \quad 32.23 \mathrm{~m}$ & \\
\hline Draught & $: \quad 12.82 \mathrm{~m}(\max : 17.45 \mathrm{~m})$ & \\
\hline Speed & $: \quad 13.3 \mathrm{kts}$ (max: 14.5kts) & \\
\hline Heading & $: 0$ & \\
\hline Coordinate & $: \quad 37.46656,-122.73109$ & \\
\hline Nav.Status & : Underway using engine & \\
\hline \multirow[t]{2}{*}{ LastReport } & : 2 days & \\
\hline & Zoom / Locate & \\
\hline & & \\
\hline
\end{tabular}

(a) Fitur Ship Info

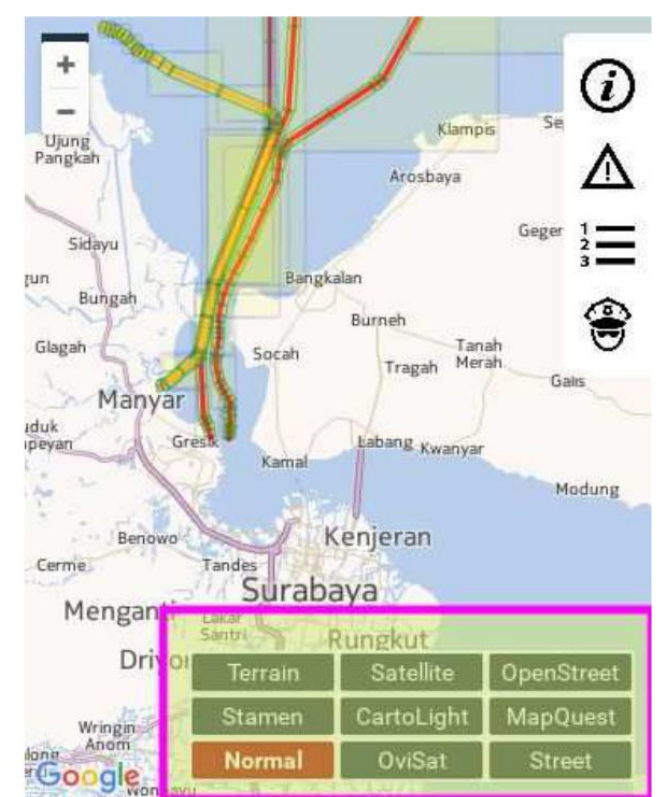

(b) Fitur Base Map 


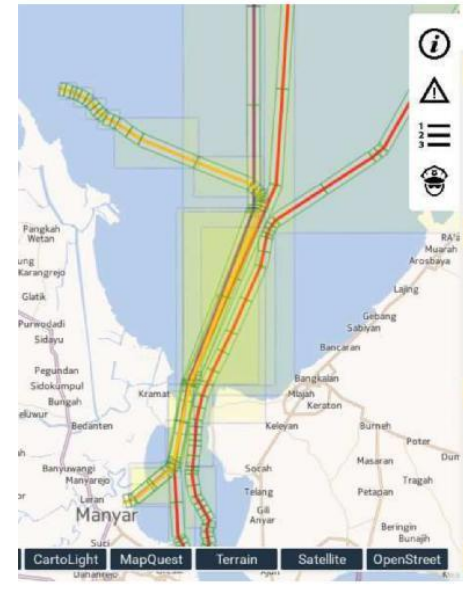

(c) Fitur Inspection Rank List

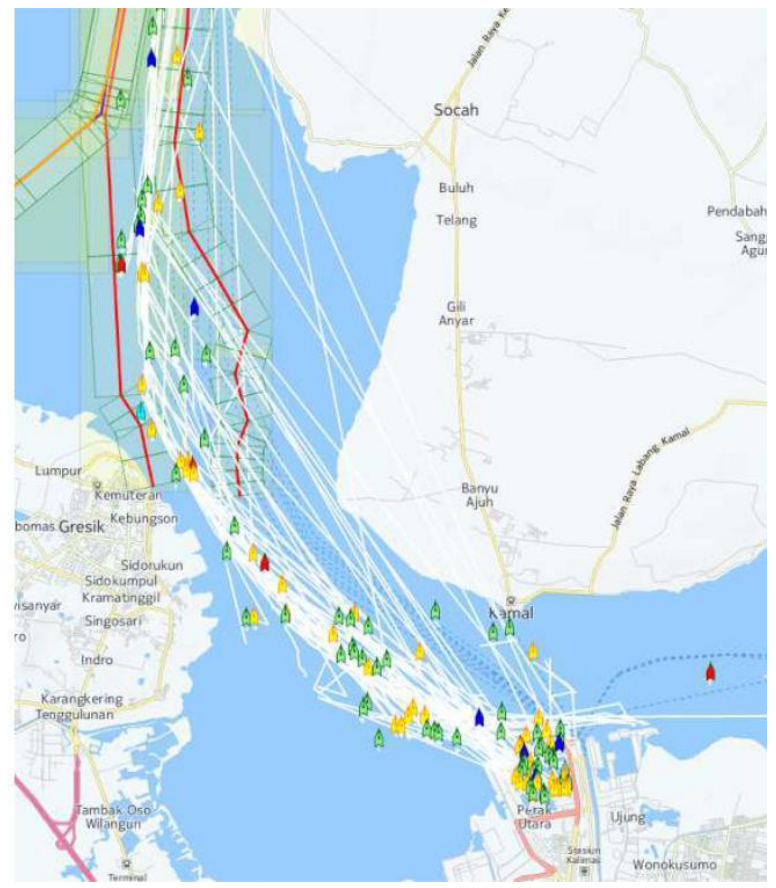

(d) Fitur Tracking Kapal

Gambar 7. Screenview dari Fitur Ship Info, Base Map, Inspection Rank List dan Tracking Kapal

\section{KESIMPULAN}

Kerangka kerja dan teknik yang sederhana telah ditunjukkan untuk memanfaatkan data AIS dalam pengembangan prototype monitoring real time pipa bawah laut dan anjungan lepas pantai. Data AIS dan kerangka kerja yang sama juga digunakan untuk mengembangkan sistem pemantauan inspeksi kapal yang dilengkapi dengan daftar kapal yang diurutkan berdasarkan tingkat keterbahayaannya. Purwarupa perangkat lunak telah dilengkapi dengan fitur-fitur dan antarmuka yang sangat sederhana. Namun demikian sudah memenuhi kebutuhan dasar untuk meningkatkan keselamatan dan keamanan di laut. Pengembangan sistem akan tetap dilakukan untuk mengadopsi kemajuan teknologi serta perubahan regulasi yang mungkin terjadi di masa depan.

\section{ACKNOWLEDGEMENT}

Penulis berterima kasih kepada pihak Kobe University Jepang untuk hibah piranti AIS receiver kepada ITS Surabaya untuk inisiasi penelitian pemanfaatan AIS sebagai sarana bantu keselamatan operasi di laut pada tahun 2007. Apresiasi juga diberikan kepada Kementerian Riset dan Pendidikan Tinggi Republik Indonesia atas bantuannya dalam bentuk hibah penelitian melalui PUPT (Program Unggulan Perguruan Tinggi) Tahun 2015 dan 2016 serta Program CPPBT (Calon Perusahaan Pemula Berbasis Teknologi) Tahun 2016.

\section{REFERENSI}

[1] T. Mou, "No Title," 2009.

[2] A. A. B. D. MASROERI A.A., K.B. ARTANA, T. PITANA., "A Review on Some Research Issues on AIS to Improve the Ship Safety Operation at sea.,” J. Marit. Res., vol. 2, pp. 11-23, 2012.

[3] P. H. PITANA T., A.A.B. DINARIYANA, K.B. ARTANA, M.B. ZAMAN, "Development of Hazard Navigation Map by using AIS data," J. Marit. Res., vol. 1, pp. 43-52, 2011.

[4] Dan Sunday, "Lines and Distance of a Point to a Line." [Online]. Available: http://geomalgorithms.com/a02_lines.html. 